\title{
Occurrence and Leave Extractable Essential Oil of Lippia multiflora M. (Verbenaceae) as Affected by Soil Acidity, Carbon, Nitrogen and Phosphorus Contents in North Cote d'Ivoire
}

\author{
Diomandé L. Barthélémy ${ }^{1}$, Brahima Koné ${ }^{1}$, Etienne V. Tia ${ }^{3}$, Tié B. Tra ${ }^{2} \&$ Yao-Kouamé Albert ${ }^{1}$ \\ ${ }^{1}$ Training and Research of Earth Sciences Unit, Department of Soil Sciences, Félix Houphouët-Boigny \\ University, Abidjan, Côte d'Ivoire \\ ${ }^{2}$ Plant and Soil Laboratory, Department of Water, Forest and Environment, Félix Houphouët-BoignyNational \\ Institute of Polytechnic, Yamoussoukro, Côte d'Ivoire \\ 3 Training and Research Unit of Biology Sciences, Department of Food Technology, Université Peleforo Gon \\ Coulibaly de Korhogo University, Korhogo, Côte d'Ivoire \\ Correspondence: Brahima Koné, Training and Research of Earth Sciences Unit, Department of Soil Sciences, \\ Félix Houphouët-Boigny University, 22 BP 562 Abidjan 22, Côte d'Ivoire. Tel: 225-0749-9875. E-mail: \\ kbrahima@hotmail.com
}

$\begin{array}{ll}\text { Received: February 24, } 2014 & \text { Accepted: March 30, } 2014 \quad \text { Online Published: April 30, } 2014 \\ \text { doi:10.5539/enrr.v4n2p115 } & \text { URL: http://dx.doi.org/10.5539/enrr.v4n2p115 }\end{array}$

\begin{abstract}
For generating a strategy of quantitative and qualitative productions of invasive Lippia multiflora, influence of soil $\mathrm{pH}$ and the contents of organic carbon $(\mathrm{C})$, total nitrogen $(\mathrm{Nt})$, total $(\mathrm{Pt})$ and available $(\mathrm{Pa})$ phosphorus were explored via dominant-abundance (DAI) and aggregation (AI) index of the species as well as the leave extractable essential oil. In three sites (Labelekaha, Taoura and Zievogo) of L. multiflora ecosystem in north Cote d'Ivoire (Sudan savanna), corresponding DAI and AI were recorded coupled with soil and leave sampling at different topographic sections. Soil $\mathrm{pH}$ and the contents of $\mathrm{C}, \mathrm{Nt}, \mathrm{Pt}$ and $\mathrm{Pa}$ were determined as well as the concentrations of essential oils. Occurrence of L. multiflora was highest in the down slope position of the landscapes with significant influence of $\mathrm{Pa}$ also noticed for essential oils mainly characterized by highest concentrations of Geranial, Neral, $\alpha$-Phellandrene, Para-Cymene, Limonene $+\beta$-Phellandrene and $\alpha$-Humulene. The effect of soil organic $\mathrm{C}$, and $\mathrm{Nt}$ were accounting for hydromorphic condition as occurred at Ziévogo. The cultivation of L. multiflora may be possible in down slope position applying $\mathrm{P}$ for high yields of leaves and essential oils mainly composed of terpenoid derivatives. Further applications of organic $\mathrm{C}$ and $\mathrm{N}$ are required for hydromorphic soil.
\end{abstract}

Keywords: toposequence, chemotype, terpenoid, ecosystem, degraded soil, nutrient interactions

\section{Introduction}

Lippia multiflora Mondenke (savanna tea) is a woody shrub in tropical ecologies, with increasing interest because of its biomedical virtues: Tea-like infusions are traditionally used as remedy against malaria fever, stress, hypertension, gastro-intestinal trouble and caugh as well as laxative (Noamesi, Adebayo, \& Bamgbose, 1985; Pham \& Koffi, 1998; Jim, Wudeneh, Mariana, \& Dan, 2000; Abena et al., 2003). Moreover, L. multiflora contains some adjutants for cosmetic (Porspi, 1992; Kanko, Sawaliho, Koné, Koukoua, \& N'guessan, 2003) and pesticides (Oladimeji, Orafidiya, Ogunniyi, \& Adewunmi, 2000; Oussou et al., 2008; Etienne et al., 2011) produces. These qualities are attributed to the properties of the leaf extractable essential oils (Irvine, 1961) accounting for 42 volatile compounds from L. multiflora and more than 126 from Lippia spp. (Maia, Silva, Andrade, \& Carreira, 2005) with specific properties that could interfere the plant attributes as individual effect (Lahlou, 2004). Specific effectiveness of terpeneols, $\alpha$ - and $\beta$-pinenes were observed on scabies by Oladimeji et al. (2000) as well as the therapeutic effects of terpene, eugenol, camphor, and menthol against divers' skin problems (Lawless, 1995; Pearlstine, 2006). In the light of these utilities of the extractable chemical compounds of essential oil of Lippia spp., it may significantly contribute to the development of pharmaceutical and cosmetic manufacturing activities in its natural growing ecosystems, as observed in savanna zone of Sub-sahara Africa. This potentiality can substantially contribute to alleviation of poverty in this region where the population 
wellbeing is more depending on informal economy (Programme des Nations Unies pour le Développement [PNUD], 2013).

For this purpose, available quantity and quality of essential oil are required meanwhile; Lippia spp. is yet an invasive plant characterized by a wide variability in the quality of essential oils (Oussou et al., 2008; Gouollaly, 2010) even within the same ecological zone and for a given genotype involving effects of seasons and environment including the soils (Bassolé et al., 2010). Previous studies of chemotypes in different ecological zones of West Africa were only descriptive (Folashade \& Omoregie, 2012; Kanko, Koukoua, \& N'guessan, 1999), missing causal and effect relationship analysis that could guide the control of both qualitative and quantitative productions of essential oil. However, such analysis was established between soil chemical characteristics and specific weed occurrence in Sub-sahara Africa ecosystems involving soil contents of C, N, P and $\mathrm{K}$ along toposequence and fertilizer effects (Udoh, Ogunkunle, \& Ndaeyo, 2007; Koné et al., 2013a; Koné, Traoré, \& Touré, 2014) somewhat depending on soil pH. Indeed, there is variability of soil fertility potential along toposequence in tropical ecosystem (Koné et al., 2009) that can affect the plant growth.

Therefore, a survey was conducted in the natural prevailing occurrence zone of L. multiflora in Cote d'Ivoire for chemical analysis of essential oils extracted from the leaves sampled at different topographic sections of landscapes considering soil $\mathrm{pH}$ as well as soil contents of organic carbon $(\mathrm{C})$, total nitrogen $(\mathrm{N})$, total $(\mathrm{Pt})$ and available (Pa) phosphorus. The aim was to identify how and which of these soil chemical characters could affect the occurrence of L. multiflora and the composition of its leaves essential oils in order to recommend a strategy for soil fertility management when developing agricultural systems for quantitative and qualitative productions.

\section{Methodology}

\subsection{Physiographical Description of the Studied Zone}

The study was conducted in the north of Cote d'Ivoire (West Africa) around the region of Korhogo concerning three sites (Labélékaha: N 858' - W 5 30' - 325 m elevation; Taouara: N 943'- W 541'- 330 m elevation; Ziévogo: N 9'28' - W 5 54' - 335 m elevation) naturally colonized by L. multiflora. The region belongs to the sudanean climatic sector as a tropical sub-humid zone with plateau landscapes of $300-400 \mathrm{~m}$ in altitude. Rainfall pattern is monomodal characterized by a long dry season period (November - May) and shorter rain season (June - October). Annual average rainfall amount and temperature are $1217 \mathrm{~mm}$ and $26.95{ }^{\circ} \mathrm{C}$, respectively, and coupled with $1609 \mathrm{~mm}$ as evapotranspiration. The bed-rock is characterized by granite and schist (Beaudou \& Sayol, 1980).

\subsection{Vegetation}

The region is characterized by dispersed blocks of secondary forests in a dominant derived savanna where, forest bands are also associated to hydrographic network (Beaudou \& Sayol, 1980). Deciduous and hardwood trees are encountered in the summit and the upper slope positions of landscape across the studied zone somewhat contrasting with the dominance of savanna vegetation species in the middle and foot slope positions. Arborescent species (Acacia sieberiana; Bridelia ferruginea; Vitellaria paradoxa; Daniella oliveri; Hymenocardia acida; Lophira lanceolata; Mitragyna Inermis; Nauclea latifolia; Pterocarpus erinaceus; Terminalia glaucescens and Piliostigma thonningii) are occurring with DAI and AI values of 1 respectively. This biotope of savanna includes L. multiflora associated with different herbaceous species as presented in Table 1 .

Table 1. Average dominant abundance and aggregation index of herbaceous species in L. multiflora community as encountered in the studied region (Labélékaha, Taouara \& Ziévogo)

\begin{tabular}{ccc}
\hline Identification & DAI & AI \\
\hline Cochlospermum planchonii & 1 & 1 \\
Aframomum latifolium & 3 & 3 \\
Melanthera scandens & 2 & 3 \\
Euclasta condylotrica & 4 & 4 \\
Hyparrhenia dissoluta & 4 & 4 \\
Hyparrhenia diplandra & 4 & 3 \\
Pennisetum polystachion & 4 & 3 \\
Sorghastrum bipennatum & 4 & 3 \\
\hline
\end{tabular}

DAI: Dominant-abundance index; AI: Aggregation index. 


\subsection{Landscape and Soil}

Dominant morpho-pedologycal landscapes in the region are characterized by plateaus with or not degraded hardpan layer in summit position accounting for $33.3 \%$ and $28.5 \%$ of total surface of the studied region respectively while; convexo-concave side interfluves are recovering $12.3 \%$ according to Beaudou and Sayol (1980). At Labélékaha, Taoura and Zievogo, L. multiflora community was encountered along the middle slope, the foot slope and peneplanated lowland with alluvial deposit respectively. Soils of hill slope were Plinthosols with Leptic character somewhere while, Acrisols and Arenosols were prevailing in the down slope. Fluvisol was exclusively occurring in lowland.

\subsection{Sampling of Plant and Soil}

In randomly selected area of about 1 ha, equally stratified sampling method (Webster \& Olivier, 1990) according to topographic sections defined as summit, upper slope, middle slope and foot slope (Rhuhe \& Walker, 1968) was applied along the hillside in each of the studied site (Labélékaha, Taoura \& Zievogo). Toposequence with azimuths of 119, 121 and 135 grades were laid in Labélékaha, Taoura and Zievogo respectively. Each of topographic section was about $100-150 \mathrm{~m}$ in length along $500-700 \mathrm{~m}$ of hillside characterized by a gentle slope $(2-5 \%)$ and high invasion of L. multiflora in places. At flowering stage of L. multiflora (November) corresponding to the physiological maturity, leaves were sampled around $11 \mathrm{~h}-12 \mathrm{~h}$ from randomly selected 32 plants dispersed within 1 ha. For a given topographic position, samples of leaves were keep together before taking $1 \mathrm{~kg}$ as composite sample which was save in carboglass before air drying in a room condition during 7 10 days. This sampling was coupled with soil profile study for characterization and 32 elemental soil samples were taken using hand augur within $0-20 \mathrm{~cm}, 20-40 \mathrm{~cm}, 40-60 \mathrm{~cm}$ and $60-80 \mathrm{~cm}$ depth neighboring $(5-10$ $\mathrm{cm}$ apart) the plants respectively. A composite sample of $2 \mathrm{~kg}$ was done for each of the soil depths in a given topographic position for all the three sites.

\subsection{Estimation of DAI and AI for L. multiflora}

The dominant-abundance indice (DAI) of L. multiflora was estimated according to Braun-Blaquet, Roussine and Negre (1952) method of species score $(1-5)$ of soil recovering rates: $1=<5 \%$ of recovering; $2=5-25 \%$ of recovering; $3=25-50 \%$ of recovering; $4=50-75 \%$ of recovering and $5=75-100 \%$. Guinochet (1973) score of species dispersion $(1-5)$ were also used for the estimation of species aggregation indice (AI): 1: individual occurrence; 2 = dispersed small groups; 3 = dispersed larger groups; $4=$ almost continuous population and $5=$ continuous population.

\subsection{Analysis of Essential Oil}

The essential oil from the leaves of L. multiflora was extracted by hydrodistillation (water and stem distillation) in a Clevenger-type apparatus (Clevenger, 2006) during 3 hours, yielding 1.0\% (v/w). Gas chromatography analyses were performed coupled with spectrometry (Hwelett-Pakard, CG 5890 serial II) for chemical volatile compounds (constituents of mono- and sesquiterpene) identification as described by Etienne et al. (2011) including comparison between the experimental gas chromatographic retention indices (RI) and fragmentation pattern with corresponding reference data (NBS5K/NIST98) as done by Adams (2007). A standard solution of n-alkanes $(\mathrm{C} 7-\mathrm{C} 26)$ was used to obtain the retention indices. Identified elements were grouped according to the molecular radicals as monoterpene and sequiterpene characterized by two isoprene units $\left(\mathrm{C}_{10} \mathrm{H}_{16}\right)$ and three $\left(\mathrm{C}_{15} \mathrm{H}_{24}\right)$ respectively. Further differentiation was done referring to oxygenated derivatives among both.

\subsection{Soil Analysis}

Soil composite samples were air dried in a room condition, grounded, and sieved $(2 \mathrm{~mm})$ before analytical process including $\mathrm{pH}$ measurement with electrode glass in soil/water $(1 / 2.5)$ solution. The content of organic carbon (C) was determined by colorimetric measurement of unreduced amount of $\mathrm{Cr}_{2} \mathrm{O}_{7}^{-}$by $\mathrm{C}$ according to Walkley and Black (Pansu \& Gauteryrou, 2003). Kjeldhal method including mineralization of organic matter at $300^{\circ} \mathrm{C}$ was used to determined soil content of total- $\mathrm{N}$ using sulphuric acid $\left(\mathrm{K}_{2} \mathrm{SO}_{4}+\mathrm{CuSO}_{4}+\mathrm{Se}\right)$ during three hours. Mineralization process and selective extraction were applied to determine the amount of total and available phosphorus using EDTA (Pansu \& Gautheryrou, 2003). Results of soil analysis were interpreted according to Baillie (2010) referring to the critical levels respectively.

\subsection{Statistical Analysis}

Mean value of soil $\mathrm{pH}$ and the contents of $\mathrm{C}, \mathrm{N}, \mathrm{Pt}$ and $\mathrm{Pa}$ were determined by descriptive statistic for every site according to soil depths along the toposequence. Pearson correlation analysis was done between abundance index (DAI) of L. Multiflora and soil contents of C, N, Pt and Pa in $0-20 \mathrm{~cm}, 20-40 \mathrm{~cm}, 40-60 \mathrm{~cm}$ and $60-$ $80 \mathrm{~cm}$ for each topographic positions respectively. Similar analyse was also done for aggregation index of 
sociability (AI) and repeated for studied sites respectively. Average value of studied chemical contents of soil in $0-40 \mathrm{~cm}$ and $40-80 \mathrm{~cm}$ was similarly used, especially, with DAI. Pearson correlation was also processed between soil characters and essential oil concentrations in leave. SAS (version 8) was used for statistical analysis considering $\alpha=0.05$, meanwhile extension up to 0.10 was accepted for correlation data interpretation.

\section{Results}

\subsection{Soil Characteristics}

Table 2. Mean values and standard deviation (SD) of C, Nt, Pt and Pa as well as $\mathrm{pH}$ in $0-20 \mathrm{~cm}, 20-40 \mathrm{~cm}, 40$ $-60 \mathrm{~cm}$ and $60-80 \mathrm{~cm}$ soil depths according to topographic sections for the three sites

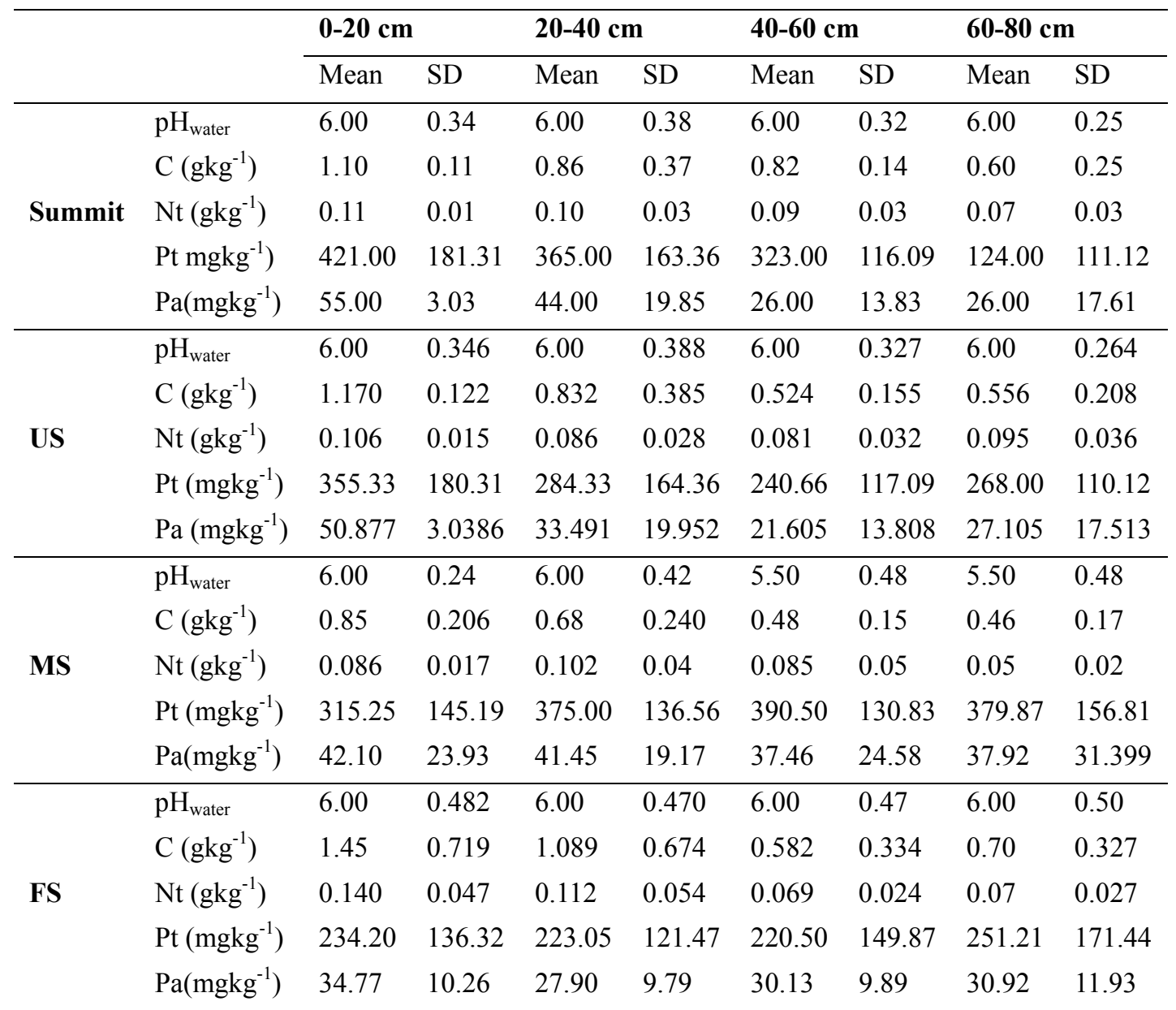

US: Upper slope; MS: Middle slope; FS: Foot slope.

Table 1 reveals moderate acidity $(5.5<\mathrm{pH}<6)$ of studied soils indifferently to soil depths and topographic positions. In topsoil $(0-20 \mathrm{~cm})$, soil content of $\mathrm{C}\left(>1 \mathrm{gkg}^{-1}\right)$ is high except for the soil in middle slope position contrasting with soil content of $\mathrm{Nt}$, exclusively low $\left(<1 \mathrm{gkg}^{-1}\right)$ whatever the topographic position when compared with the critical level respectively. Soil contents of Pt is ranging moderately with wide variability while, that of $\mathrm{Pa}$ is high $\left(>10 \mathrm{mg} \mathrm{kg}^{-1}\right)$.

\subsection{Occurrence of L. multiflora Referring to Soil}

There is wide irregularity in the occurrence of L. multiflora along the toposequences: no occurrence is observed at the summit and the upper slope positions contrasting with the data recorded for the middle and foot slopes, especially at Taoura and Ziévogo with dominant-abundances of 2 and 3 respectively, but, with the same estimated value of aggregation sociability index of 1 . Dominant-abundance index of 2 is also recorded at the middle slope position in Labélékaha. Across the three sites surveyed, down slope position (middle and foot slopes) is likely more favorable to L. multiflora occurrence than the hill slope position (summit and upper slope). 
Table 3. Soil contents of $\mathrm{C}, \mathrm{Nt}$, Pt, and $\mathrm{Pa}$ as well as the $\mathrm{pH}$ under L. multiflora occurrence according to soil depths in studied sites

\begin{tabular}{|c|c|c|c|c|c|c|c|}
\hline Site & $\begin{array}{l}\text { Topographic } \\
\text { Sections }\end{array}$ & Depth (cm) & $\mathbf{p H}_{\text {water }}$ & $\mathrm{C}\left(\mathrm{gkg}^{-1}\right)$ & Nt $\left(\mathrm{gkg}^{-1}\right)$ & Pt $\left(\mathrm{mgkg}^{-1}\right)$ & $\mathrm{Pa}\left(\mathrm{mgkg}^{-1}\right)$ \\
\hline \multirow{4}{*}{ Taouara } & \multirow{4}{*}{ Foot slope } & $0-20$ & 6.0 & 0.66 & 0.09 & 534 & 42 \\
\hline & & $20-40$ & 6.5 & 0.48 & 0.08 & 483 & 34 \\
\hline & & $40-60$ & 6.5 & 0.30 & 0.06 & 405 & 30 \\
\hline & & $60-80$ & 6.0 & 0.30 & 0.06 & 378 & 34 \\
\hline \multirow{4}{*}{ Labélékaha } & \multirow{4}{*}{ Middle slope } & $0-20$ & 6.0 & 0.98 & 0.11 & 475 & 68 \\
\hline & & $20-40$ & 6.0 & 0.79 & 0.12 & 500 & 63 \\
\hline & & $40-60$ & 5.0 & 0.49 & 0.04 & 488 & 63 \\
\hline & & $60-80$ & 5.0 & 0.49 & 0.04 & 488 & 63 \\
\hline \multirow{4}{*}{ Ziévogo } & \multirow{4}{*}{ Foot slope } & $0-20$ & 5.5 & 1.99 & 0.16 & 438 & 21 \\
\hline & & $20-40$ & 5.5 & 1.81 & 0.17 & 387 & 16 \\
\hline & & $40-60$ & 6.0 & 0.86 & 0.11 & 456 & 11 \\
\hline & & $60-80$ & 6.0 & 0.86 & 0.11 & 456 & 11 \\
\hline
\end{tabular}

The occurrence of L. multiflora is observed associated to wide range of soil $\mathrm{pH}(5.0-6.5)$, as well as for the contents of C $\left(0.30-1.99 \mathrm{~g} \mathrm{~kg}^{-1}\right)$, Nt $\left(0.04-0.17 \mathrm{~g} \mathrm{~kg}^{-1}\right)$, Pt $\left(378-534 \mathrm{mg} \mathrm{kg}^{-1}\right)$ and Pa $\left(11-68 \mathrm{mg} \mathrm{kg}^{-1}\right)$. However, the sites of Taoura and Labélékaha are characterized by $\mathrm{pH}$ range of about (6.0) and lower content than the critical level of $\mathrm{C}\left(<1 \mathrm{~g} \mathrm{~kg}^{-1}\right)$ in the topsoil $(0-20 \mathrm{~cm})$ while, lower $\mathrm{pH}(<5.5)$ is observed for Ziévogo. In turn, soil contents of $\mathrm{Nt}\left(<1 \mathrm{~g} \mathrm{~kg}^{-1}\right)$ and Pt $\left(378-534 \mathrm{mg} \mathrm{kg}^{-1}\right)$ are likely in the same ranges across the three sites under L. multiflora occurrence respectively, but, soil Pa contents $\left(21-11 \mathrm{mg} \mathrm{kg}^{-1}\right)$ at Ziévogo are not much as observed for the other sites $\left(30-68 \mathrm{mg} \mathrm{kg}^{-1}\right)$ according to Table 3 .

Roughly, there is high affinity between low occurrences of L. multiflora with soils characterized by high $\mathrm{pH}$ associated with low content of $\mathrm{C}$ in $0-40 \mathrm{~cm}$ depth while, the increase of $\mathrm{Nt}$ in $40-80 \mathrm{~cm}$ depth is more related to the high density of this species. These contrasts are not as much for Pt and Pa referring to the indicators (DAI and AI) of L. multiflora occurrence.

No significant correlation is noticed between DAI and soil parameters in $0-20 \mathrm{~cm}$ and $20-40 \mathrm{~cm}$ depths contrasting with the negative values $(-0.76$ and -0.86$)$ significantly observed for $\mathrm{Pa}$ in $40-60 \mathrm{~cm}(p=0.04)$ and $60-80 \mathrm{~cm}(p=0.09)$. Although the correlation values $(-0.62$ and -0.66$)$ of AI are also negative and high for Pa under $40 \mathrm{~cm}$ soil depth, they are not significant and low values are observed for Pt. Significant $(p=0.04)$ and high correlation value of 0.78 is noticed only for soil $\mathrm{pH}$ with positive magnitude in $40-60 \mathrm{~cm}$ depth.

Beside the high correlation value recorded between DAI and AI $(\mathrm{r}=0.99 ; p<0.001)$, it is significantly recorded positive correlation values for DAI and soil content of $\mathrm{Pa}$ in $0-40 \mathrm{~cm}(0.96)$ as well as in $40-80 \mathrm{~cm}(0.89)$ at Labélékaha. No significant correlation accounts for the site of Taoura while, soil $\mathrm{pH}$ and the content of $\mathrm{Nt}$ are concerned at Ziévogo $(\alpha=0.10)$ coupled with negative magnitude of correlation for soil $\mathrm{pH}$ in $0-40 \mathrm{~cm}$. 
Table 4. Coefficients (r) of Pearson correlation between DAI and soil pH, C, Nt, Pt, and Pa according to topographic sections as well as for AI

\begin{tabular}{|c|c|c|c|c|c|c|c|c|}
\hline \multirow[b]{3}{*}{ Soil Parameters } & \multicolumn{8}{|c|}{ Correlation Coefficient (r) } \\
\hline & \multicolumn{2}{|c|}{ Summit } & \multicolumn{2}{|c|}{ Upper Slope } & \multicolumn{2}{|c|}{ Middle Slope } & \multicolumn{2}{|c|}{ Foot Slope } \\
\hline & DAI & $\mathrm{AI}$ & DAI & AI & DAI & AI & DAI & $\overline{\mathrm{AI}}$ \\
\hline $\mathrm{pH}$ & . & . & .. & . & $-0.13 n s$ & $0.13 \mathrm{~ns}$ & $0.20 \mathrm{~ns}$ & $0.28 \mathrm{~ns}$ \\
\hline $\mathrm{C}$ & . . & . . & . . & . . & $0.19 \mathrm{~ns}$ & $0.19 \mathrm{~ns}$ & $0.06 \mathrm{~ns}$ & $0.07 \mathrm{~ns}$ \\
\hline $\mathrm{Nt}$ & . & . & . & . & $0.09 \mathrm{~ns}$ & $0.09 \mathrm{~ns}$ & $0.19 \mathrm{~ns}$ & $0.05 \mathrm{~ns}$ \\
\hline $\mathrm{Pt}$ & . & . & . & . & $0.58^{*}$ & $0.004 \mathrm{~ns}$ & $0.39 *$ & $0.20 \mathrm{~ns}$ \\
\hline $\mathrm{Pa}$ & $\ldots$ & . . & . & . . & $0.64 *$ & $0.64 *$ & $-0.59 *$ & $0.44^{*}$ \\
\hline
\end{tabular}

$\ldots$ :. Not available; * : significant for $\alpha=0.05$; ns: Non significant for $\alpha=0.05$.

Positive and significant $(p=0.011)$ similar correlation values are observed for Pa when referring to DAI and AI respectively in the middle slope position. In opposite, negative and significant $(p=0.001)$ correlation accounts for Pa and DAI as recorded in the foot slope position also contrasting with that observed significantly $(p=0.023)$ between Pa and AI. In turn, correlation values for Pt are only significant for DAI in the middle slope $(p=0.004)$ and foot slope $(p=0.040)$ positions with positive magnitude. No significant correlation is observed for the other soil parameters whatever the coefficient of L. multiflora occurrence (Table 4).

\subsection{Essential Oil Composition and Relation With Soil}

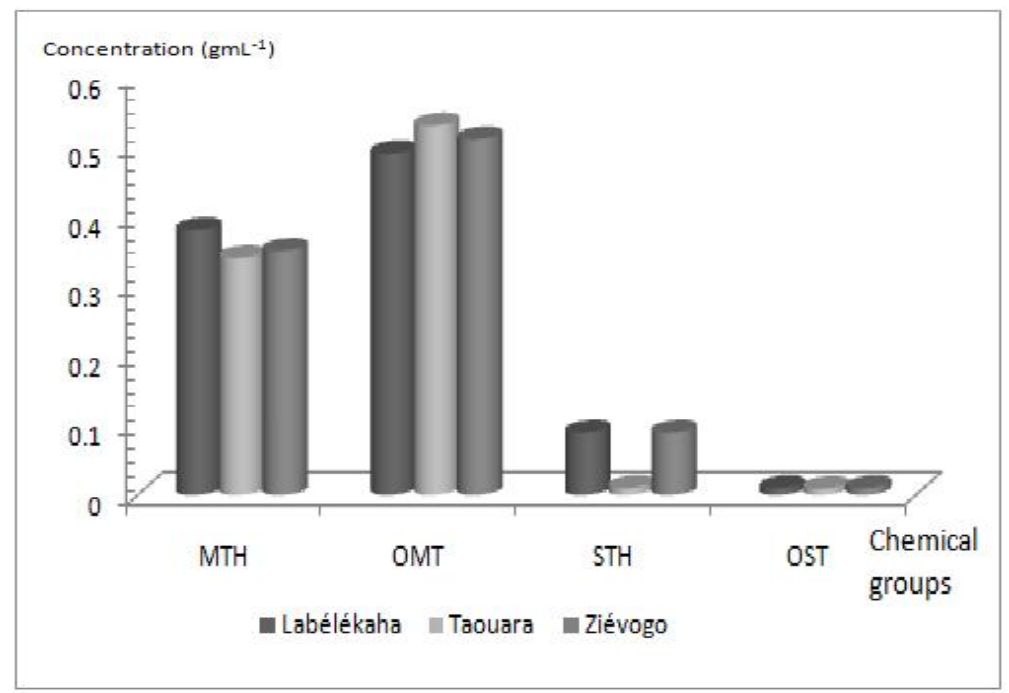

Figure 1. Average concentrations of different groups of chemical compounds (MTH, OMT, STH and OST) as determined in essential oil of L. multiflora from the topographic sections of Labélékaha, Taoura and Ziévogo (MTH: Monoterpene hydrocarbon; OMT: Oxygenated Monoterpene; STH: Sesquiterpene hydrocarbon; OST: Oxygenated Sesquiterpene)

Four groups of chemical compounds are extracted from essential oil of Lippia: Monoterpene and Sesquiterpene varying as hydrocarbon and oxygenated derivatives. Relatively, the concentrations within a chemical group are in the same ranges for all the localities. Roughly, hydrocarbon (MTH) and oxygenated (MTO) monoterpenes have almost the same concentrations meanwhile; the concentration of sequiterpene hydrocarbon (STH) is likely $2-3$ times greater than that of oxygenated sequiterpene (OST). Moreover, the concentrations of monoterpenes appeared to be $2-4$ times greater than that of sequiterpene derivatives respectively. The concentrations are ranging from $0.05 \mathrm{~g} \mathrm{ml}^{-1}$ (OST) to $0.5 \mathrm{~g} \mathrm{ml}^{-1}$ (MTH) as 10 times increasing ratio (Figure 1). 
Table 5. Volatile substance concentrations in essential oil of $L$. multiflora according to studied localities

\begin{tabular}{|c|c|c|c|}
\hline \multicolumn{4}{|c|}{ Volatile Substance Concentrations $\left(\mathrm{g} \mathrm{ml}^{-1}\right)$} \\
\hline & Labélékaha & Taouara & Ziévogo \\
\hline \multicolumn{4}{|l|}{ Monoterpene Hydrocarbons } \\
\hline$\alpha$-Pinene & 0.10 & 0.08 & 0.09 \\
\hline Sabinene & 0.05 & 0.07 & 0.06 \\
\hline Myrcene & 0.10 & 0.10 & 0.10 \\
\hline$\alpha$-Phellandrene & 1.39 & 1.08 & 1.15 \\
\hline Para-Cymene & 0.97 & 1.05 & 1.01 \\
\hline Limonène $+\beta$-Phellandrene & 0.87 & 0.84 & 0.85 \\
\hline (E)- $\beta$-Ocimene & 0.19 & 0.14 & 0.15 \\
\hline Linalol & 0.15 & 0.12 & 0.13 \\
\hline Total $\left(\mathrm{g} \mathrm{ml}^{-1}\right)$ & 3.82 & 3.48 & 3.54 \\
\hline \multicolumn{4}{|l|}{ Oxygenated monoterpènes } \\
\hline 6-methyl-5-hepten-2-one & 0.16 & 0.16 & 0.16 \\
\hline 1,8 Cineol & 0.04 & 0.07 & 0.05 \\
\hline Cis-para-menth-2-en-1-ol & Trace & 0.03 & Trace \\
\hline Citronellal & 0.04 & 0.04 & 0.04 \\
\hline (Z)-isocitral & 0.09 & 0.07 & 0.08 \\
\hline (E)-isocitral & 0.15 & 0.12 & 0.13 \\
\hline Nerol & 0.06 & Trace & Trace \\
\hline Neral & 1.95 & 2.09 & 1.99 \\
\hline Geraniol & 0.05 & 0.06 & 0.05 \\
\hline Geranial & 2.32 & 2.66 & 2.48 \\
\hline Thymol & 0.04 & Trace & Trace \\
\hline Total $\left(\mathrm{g} \mathrm{ml}^{-1}\right)$ & 4.90 & 5.30 & 5.15 \\
\hline \multicolumn{4}{|l|}{ Sesquiterpene hydrocarbons } \\
\hline (E)- $\beta$ Caryophyllene & 0.20 & 0.25 & 0.23 \\
\hline$\alpha$-Humulene & 0.55 & 0.55 & 0.55 \\
\hline (E)- $\beta$-Farnesene & 0.06 & 0.08 & 0.07 \\
\hline Germacrene D & 0.10 & 0.06 & 0.08 \\
\hline$\beta$-Bisabolene & 0.05 & 0.06 & 0.06 \\
\hline Total $\left(\mathrm{g} \mathrm{ml}^{-1}\right)$ & 0.96 & 1.00 & 0.99 \\
\hline \multicolumn{4}{|l|}{ Oxygenated sesquiterpenes } \\
\hline (E)-Nerolidol & 0.08 & 0.05 & 0.07 \\
\hline Caryophyllene Oxide & 0.05 & 0.04 & 0.05 \\
\hline Total $\left(\mathrm{g} \mathrm{ml}^{-1}\right)$ & 0.13 & 0.09 & 0.12 \\
\hline Overall concentration $\left(\mathrm{g} \mathrm{ml}^{-1}\right)$ & 9.87 & 9.81 & 9.63 \\
\hline
\end{tabular}

Monoterpene hydrocarbon is composed of eight volatile substances against 11 as oxygenated derivatives which are minor (2) among sesquioxydes containing 5 hydrocarbon derivatives. The concentrations of volatile substances are relatively similar in a given site for monoterpenes hydrocarbon as well as for sesquioxyd compounds. However, essential oil extracted from the Lippia of Labélékaha is characterized by Nerol and 
Thymol concentrations which are missing monoterpenoids in the essential oil from Taoura and Ziévogo. Exceptionally, Cis-para-menth-en-1-ol is determined in the essential oil of L. multiflora from Taoura. In turn, major substances (high concentrations) are recorded in the same range of concentrations in essential oil extracted from the leaves of L. multiflora across the studied sites, including, 3 ( $\alpha$-Phellandrene, Para-Cymene, Limonene $+\beta$-Phellandrene) of monoterpene hydrocarbons and 2 (Neral and Geramial) of oxygenated monoterpenes. Only $\alpha$-Humulène out stands among the sesquiterpene strongly contrasting with oxygenated derivatives which have lowest concentrations (Table 5).

Similarly, all the major volatile substances are significantly $(p<0.01)$ correlated to soil contents of $\mathrm{Pt}(0.61)$ and $\mathrm{Pa}(0.72)$ with positive magnitude. Significant $(p=0.01)$ correlations with similar value $(-0.49)$ are observed only for soil content of Pt indifferently to volatile substances of the essential oil with negative magnitude at Taoura.

As observed for Labélékaha, soil contents of Pt $(\alpha=0.05)$ and Pa $(\alpha=0.10)$ at Ziévogo are significantly correlated with all the major volatile substances of essential oil as well as for soil content of $\mathrm{Nt}(\alpha=0.10)$ with positive correlation values $(0.39)$ referring only to $\alpha$-Phellandrene, Para-Cymene and Limonene $+\beta$-Phellandrene respectively. Positive and significant correlation values ( 0.49 and 0.41$)$ are also observed for soil content of $C$ with no restriction among the volatile substances.

\section{Discussion}

\subsection{Occurrence of Lippia as Affected by Soil Characteristics}

Soil $\mathrm{pH}$ values were ranging between 5.5 and 6 as moderate acidity that might be favorable for the growth of many vegetal species in the studied area (Koné, Saïdou, Camara, \& Diatta, 2010a; Koné, Ettien, Amadji, Diatta, \& Camara, 2010b) including L. multiflora as asserted by Alui et al. (2011). However, preferential occurrence of this species was noticed along the toposequence during the survey: Lowest occurrence accounted for the hill slope (summit and upper slope) position of landscape contrasting with the highest occurrence observed along the down slope (middle and foot slope) position. Soil morphological variability along the landscapes of the studied region could be involved in this clustering. In fact, there is highest content of gravels in the soil of hill slope contrasting with that of juxtaposed soils of down slope position which are dominated by colluviums from hill slope (Wambeke, 1974; Koné et al., 2009). This mechanical constraint could have impaired the root development of L. multiflora as described for similar species in such conditions (Boa, 1989) meanwhile, woody trees with more robust roots are frequently observed in the biotope of hill slope (Beaudou \& Sayol, 1980) further constraining the occurrence of L. multiflora as C4 plant requiring sunlight (Yao-Kouamé \& Fako, 2008).

Soil acidity and the content of phosphorus in subsoils $(40-60 \mathrm{~cm}$ and $60-80 \mathrm{~cm})$ significantly influenced DAI and AI respectively: Increase of soil pH in $40-80 \mathrm{~cm}$ depth was associated with highest DAI of L. multiflora in contradiction with the result relative to $0-40 \mathrm{~cm}$ depth. Indeed, the increase of $\mathrm{pH}$ in subsoil could be a consequence of cations $\left(\mathrm{Ca}^{2+}, \mathrm{Mg}^{2+}\right.$ and $\left.\mathrm{K}^{+}\right)$accumulation resulting from leaching of topsoil (Dabin, 1985) hence, becoming more acidic. Thereby, the opposite correlations (positive and negative) established between DAI and soil $\mathrm{pH}$ in $0-40 \mathrm{~cm}$ and $40-80 \mathrm{~cm}$ respectively. Moreover, the increase of soil content of $\mathrm{Nt}$ in $40-80 \mathrm{~cm}$ depth was likely associated to similar trend of DAI at Ziévogo. Referring to soil $\mathrm{pH}$, the increase of $\mathrm{Nt}$ could be more related to nitrate $\left(\mathrm{N}_{-} \mathrm{NO}_{3}{ }^{-}\right)$nitrogen (Kleiner, 1981; Dyhr-Jensen \& Brix, 1996) that could be leached as

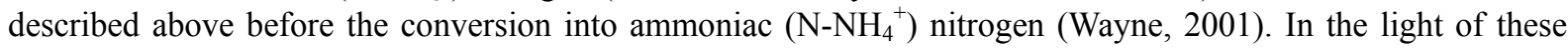
analyses, depletion of topsoil contents of cations can be favorable to L. multiflora occurrence in soil with poor content of gravels. In turn, anionic compounds as $\mathrm{P}\left(\mathrm{HPO}_{4}{ }^{2-}, \mathrm{H}_{2} \mathrm{PO}_{4}{ }^{-}\right)$should be high throughout the rooting profile $(0-80 \mathrm{~cm})$ for increasing of DAI of L. multiflora. Therefore, $\mathrm{P}$ is likely the most important nutrient for the cultivation of L. multiflora when developing specific agricultural systems (Yao-Kouamé \& Fako, 2008). However, there was no trend of soil contents of P across the studied sites in relation with DAI. Thus, we assume indirect effect of soil P content on L. multiflora occurrence as result of some interactions with other nutrients such as specific cations (Marschner \& Cakmak, 1986; Koné et al., 2011), which need to be confirmed by further study.

However, hydromorphic character of the soil at Ziévogo was most pronounced compared with that of the other studied sites illustrating highest moisture availability that could have supported the growth of L. multiflora (Rumasz-Rudnicka, Koszanski, \& Woroniecki, 2008) as attested by the highest density of 3 recorded during the survey.

Beside of the characterization of L. multiflora occurrence, our study confirms that soil chemical degradation is more related to invasive vegetation occurrence (Koné et al., 2013b) emphasizing the importance of soil cations in this process while contrasting with that of anions. However, further investigations are required in other 
ecological zones for the generalizing such assumption.

\subsection{Essential oil and Soil Relationship}

The monoterpenes compounds $\left(8.52-8.78 \mathrm{mg} \mathrm{L}^{-1}\right)$ were the most important chemical components of the essential oils as extracted from the leave of $L$. multiflora harvested across the studied sites. This result is concordant with that of Loza-Tavera (1999) likewise for Bruneton (1993). The highest concentrations of oxygenated derivatives as monoterpenoids further confirm the work done by Oussou et al. (2008). However, the major volatile substances were identified as Geranial, Neral, $\alpha$-Phellandrene, Para-Cymene, Limonene $+\beta$-Phellandrene and $\alpha$-Humulene somewhat differing with that of lowest latitude $\left(<7^{\circ} \mathrm{N}\right)$ localities even in Cote d'Ivoire (Kanko et al., 2003; Kanko, 2010; Etienne et al., 2011) and Burkina Faso (Bassolé et al., 2010). The difference observed can account for genetic diversity of Lippia multiflora (Adou et al., 2011) at certain level in addition to the effect of the latitude variation (Purseglove, Brown, Green, \& Robbins, 1981). However, environment effect as described by Besombes (2008) can stand out among variability factors of essential oil quality in a restricted area as much as our studied region. Soil contents of $\mathrm{P}$ as total and available $\mathrm{P}$ has shown significant influences on the concentrations of major volatile substances determined in extractable essential oils across the studied sites. This result could be related to temporal character of bounded P (e.g. Al-P, Fe-P and Ca-P) which may be stable in low soil pH $(<5.5)$ condition (Sanchez, 1976) while, higher soil pH values were often determined for the studied sites. Hence, releasing process of bounded -P can occur as consequence of isomorphic substitution against other anions (Colomb, Debaekey, Jouan, \& Nolot, 2006). Therefore, a positive correlation between Pt and volatile substances of essential oil are coupled with that observed with $\mathrm{Pa}$ at Labélékaha while, it was recorded negative correlations at Taoura as consequence of limited release of -P contributing to induce no significant relationship between $\mathrm{Pa}$ and the concentrations of volatile substances. This assumption is also related to the results observed at Ziévogo differing to the other studied sites with hydromorphic soil and the influence of soil contents of $\mathrm{C}$ and $\mathrm{Nt}$ in addition to the opposites influences of $\mathrm{Pt} v s$. $\mathrm{Pa}$. Moreover, Neral, Geramial and $\alpha$-Humulene concentrations were not affected by soil content of $\mathrm{Nt}$ at all $(\alpha=$ 0.05 and $\alpha=0.10$ ).

In the light of these analyses, phosphorus is unarguably the most important nutrient for qualitative production of extractable essential oil of Lippia multiflora. This potential effect of P-nutrition in essential oil production was tested by R. Tunctürk and M. Tunctürk (2006) and optimum rate was about $40 \mathrm{~kg} \mathrm{P}^{-1}$ but no similar investigation was known for the production of essential oil of Lippia multiflora. Therefore, further studies should explore the effect of P-rates in quantitative and qualitative productions of volatile substances contained in the essential oil of this aromatic plant. In fact, $\mathrm{P}$ is a component of active isoprene (Isopentenyl pyrophosphate), the radical of terpenoid compounds (Nes \& Mckean, 1977) kwon to be widely involved in the physiology of aromatic plants with significant influence of phosphorus in biosynthesis of essential oils (Olle \& Bender, 2010).

However, nutrient interaction with phosphorus and moisture availability in soil can be of interest in essential oils synthesis: soil moisture can affect Linalol synthesis (Arganosa, Sosulski, \& Slikard, 1998) with increasing effect on organic matter contribution as well as for nitrogen (Hussien, 1995). The actual study mainly contributed to identify the components of mineral nutrition of Lippia multiflora emphasizing their influence on chemotype variability of the extractable essential oil. Therefore, knowledge is improve for development of sustainable production strategy of this species with high economical potential but still growing as invasive vegetal.

\section{Conclusion}

In addition to soil acidity already identified as criteria of the occurrence of Lippia multiflora in West Africa ecosystems, our study revealed the importance of mechanical constraints as induced by soil morphology and that of bioavailability of phosphorus. The major volatile substances were Geranial, Neral, $\alpha$-Phellandrene, Para-Cymene, Limonene $+\beta$-Phellandrene and $\alpha$-Humulene. Phosphorus has influenced their concentrations respectively and soil moisture was likely favorable to similar effect of nitrogen somewhat contrasting with that of organic matter. Study of response to the rates of $\mathrm{P}$ and $\mathrm{N}$ was suggested considering different ecologies in hydromorphic and aerobic conditions in order to deepen knowledge for quantitative and qualitative productions of L. multiflora.

\section{References}

Abena, A. A., Diatewa, M., Gakosso, G., Gbeassor, M., Hondi-Assah, T. H., \& Ouamba, J. M. (2003). Analgesic, antipyretic and anti-inflammatory effects of essential oil of Lippia multiflora. Fitoterapia, 74, 231-236. http://dx.doi.org/10.1016/S0367-326X(03)00029-7

Adam's, R. P. (2007). Identification of Essential Oil Components by Gas Chromatography/Mass Spectrometry 
(4th ed.). United States, U.S: Carol stream.

Adou, K. E., N'guetta, A. S. P., Kouassi, A., Kanko, C., Yao-Kouamé, A., Sokouri, D. P., \& Coulibaly, M. Y. (2011). Caractérisation agromorphologique et identification de populations de Lippia multiflora, une verbénacée sauvage. Journal of Applied Biosciences, 37, 2441-2452. Retrieved from www.m.elewa.org/JABS/2011/37/4. pdf

Aké, A. L. (2009). Diversité spécifique de Lippia multiflora (Verbenaceae) en Afrique intertropicale. Utilisations traditionnelles de quelques unes de ces espèces en Afrique de l'Ouest. Discours inaugural des premières journées scientifiques de valorisation de Lippia multiflora et autres plantes (Unpublished speech). Yamoussoukro, Côte d'Ivoire.

Alui, K. A., Yao-Kouamé, A., Ballo, K. C., Kouadio, K. P., N'guessan, K. A., \& Nangah, K. Y. (2011). Comportement de deux morphotypes de Lippia multiflora (Verbenaceae) sur ferralsols de la région de Yamoussoukro, Côte d'Ivoire. Journal of Applied Biosciences, 38, 2592-2601. Retrieved from www.m.elewa.org/JABS/2011/38/10.pdf

Ameyaw, Y. (2009). A growth regulator for the propagation of Lippia multiflora Moldenke, a herbal for the management of mild hypertension in Ghana. Journal of Medicinal Plants Research, 3(9), 681-685. Retrieved from www.academicjournals.org/jmpr/PDF/pdf2009/Sept/Ameyaw.pdf

Arganosa, G. C., Sosulski, F. W., \& Slikard, A. E. (1998). Seed yield and essential oil of northern-grown coriander (Coriandrum sativum L.). Journal of Herbs: Spices and Medicinal Plants, 6(2), 23-32. http://dx.doi.org/10.1300/J044v06n02_03

Avenard, J.-M. (1971). Aspects de la géomorphologie: Le milieu naturel de la Côte d'Ivoire. Paris: Orstom. Retrieved from www.documentation.ird.fr/hor/fdi:16368

Baillie, I. (2010). Autralian soil and land survey field handbook -by National Committee on Soil and Terrain. European Journal of Soil Science, 61(1), 1-153. http://dx.doi.org/10.1111/j.1365-2389.2009.01195.x

Bassolé, I. H. N., Méda, A. L., Bayala, B., Tirogo, S., Franz, C., Novak, J., ... Dicko, M. H. (2010). Composition and antimicrobial activities of Lippia multiflora Moldenke, Mentha x piperita L. and Ocimum basilicum L. Essential oils and their major monoterpènes alcohols alone and in combinaition. Molecules, 15(11), 7825-7839. http://dx.doi.org/10.3390/molecules 15117825

Beaudou, A. G., \& Sayol, R. (1980). Etude pédologique de la région de Boundiali-Korhogo (Côte d'Ivoire). Cartographie et typologie sommaire des sols. Feuille Korhogo-Feuille Boundiali à 1/200.000. Notice explicative. Paris: Orstom. Retrieved from www.documentation.ird.fr/hor/fdi:10054

Besombes, C. (2008). Contribution à l'étude des phénomènes d'extraction hydro-thermomécanique d'herbes aromatiques: Applications généralisées. Journal of Clinical Investigation, 118, 879-893. http://dx.doi.org/10.1172/JCI32865

Boa, D. (1989). Caractérisation, propriétés hydrodynamiques, contraintes et potentialité des sols gravillonnaires: Cas de Booro-Borotou, Région de Touba, Nord-ouest de la Côte d'Ivoire (Unpublished doctoral dissertation). Université de Cocody, Abidjan, Côte d'Ivoire.

Bouquet, A., \& Debray, M. (1974). Plantes médicinales de Côte d'Ivoire. Paris: Orstom. Retrieved from www.documentation.ird.fr/hor/fdi:06894

Braun-Blanquet, J., Roussine, N., \& Negre, R. (1952). Les groupements végétaux de la France méditerranéenne. Montpellier: Service de la carte des groupements végétaux. Retrieved from www.sudoc.fr/098667661

Bruneton, J. (1993). Pharmacognosie: phytochimie, plantes médicinales (4ème ed.). Paris: Tec \& Doc, Lavoisier.

Clevenger, J. F. (2006). Apparatus for the determination of volatile oil. Journal of the American Pharmaceutical Association, 17, 345-349. http://dx.doi.org/10.1002/jps.3080170407

Colomb, B., Debaekey, P., Jouan, C., \& Nolot, J. M. (2006). Phosphorus management in low input stockless systems: crop and soil responses to contrasting $\mathrm{P}$ regimes in a 36 year experiment in southern France. European Journal Agronomy, 26(2), 154-165. http://dx.doi.org/10.1016/j.eja.2006.09.004

Dabin, B. (1985). Les sols tropicaux acides. Paris: Orstom. Retrieved from www.documentation.ird.fr/hor/fdi:21075

Dyhr-Jensen, K., \& Brix, H. (1996). Effects of pH on ammonium uptake by Typha latifolia L. Plant, Cell and Environment, 19, 1431-1436. http://dx.doi.org/10.1111/j.1365-3040.1996.tb00022.x 
Etienne, V. T., Augustin, A. A., Sébastien, L. N., Gnago, A., Jean, T. M. P. L., \& Menut, C. (2011). Chemical Composition and Insecticidal Activity of Essential oils of two Aromatic plants from Ivory Coast against BemisiatabaciG. (Hemiptera: Aleyrodidae). Natural Product Communications, 6(8), 1183-1188. Retrieved from www.ncbi.nlm.nih.gov/pubmed/21922931

Folashade, K. O., \& Omoregie, E. H. (2012). Essential oil of Lippia multiflora Moldenke. Journal of Applied Pharmaceutical Science, 2(1), 15-23. Retrieved from www.japsonline.com/admin/php/uploads/334_pdf.pdf

Gouollaly, T., Nkounkou, L. C., Mahmout, Y., Ouamba, J.-M., Abena, A. A., Chalcat, J.-C., \& Figueredo, G. (2010). Variation in the chemical composition of the essential oils of different organs of domesticated Lippia multiflora Moldenke. African Journal of Biotechnology, 9(41), 7009-7013. http://dx.doi.org/10.5897/AJB10.344

Guinochet, M. (1973). La phytosociologie. Collection d'écologie I. Paris: Masson.

Hondi-Assah, C., Abena, A. A., Kokolo, J., Badila, C., \& Diatewa, M. (2003). Effets hépatoprotecteurs de Lippia multiflora et d'un phytomédicament congolais. Phytotherapie, 1(5), 135-140. Retrieved from http://cat.inist.fr/?aModele=afficheN\&cpsidt $=16314382_{-}$

Hussien, M. S. (1995). Response of Growth, Yield and Essential Oil of Coriander and Dill to Different Nitrogen Sources. Egyptian Journal of Horticulture, 22, 1-10. Retrieved from http://eurekamag.com/research/033/212/response-growth-yield-essential-oil-coriander-dill-diverse-nitrgen-s ources.php

Irvine, F. R. (1961). Woody plants of Ghana with special reference to their uses (1st ed.). London: Oxford university press.

Kanko, C. (2010). Contribution à l'étude phytochimiques de plantes médicinales et aromatiques de Côte d'Ivoire: Activités analgésique et anti-inflammatoire de stérols isolés de l'écorce de Parkia biglosa (Mimosaceae) (Unpublished doctoral dissertation). Université de Cocody, Abidjan, Côte d'Ivoire.

Kanko, C., Koukoua, G., \& N'guessan, Y. T. (1999). Composition and intraspecific variability of the leaf oil of Lippiamultiflora Mold. from the Ivory Coast. Journal of Essential Oil Research, 11(2), 153-158. http://dx.doi.org/10.1080/10412905.1999.9701097

Kanko, C., Sawaliho, B. E., Koné, S., Koukoua, G., \& N'guessan, Y. T. (2003). Étude des propriétés physico-chimiques des huiles essentielles de Lippia multiflora, Cymbopogon citratus, Cymbopogon nardus,

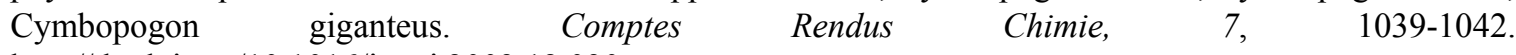
http://dx.doi.org/10.1016/j.crci.2003.12.030

Kleiner, D. (1981). The transport of $\mathrm{NH}_{3}$ and $\mathrm{NH}_{4}{ }^{+}$across biological membranes. Biochimica et Biophysica Acta, 639, 41-52. Retrieved from www.ncbi.nlm.nih.gov/pubmed/7030397

Koné, B., Amadji, G. L., Touré, A., Togola, A., Mariko, M., \& Huat, J. (2013b). A Case of Cyperusspp. and Imperata cylindrica Occurrences on Acrisol of the Dahomey Gap in South Benin as Affected by Soil Characteristics: A Strategy for Soil and Weed Management. Applied and Environmental Soil Science, 2013, 601058. Maroco: Windawi Plublishing Corporation. http://dx.doi.org/10.1155/2013/601058

Koné, B., Amadji, G. L., Touré, A., Yao-Kouamé, A., Angui, T. P., \& Huat, J. (2013a). Soil characteristic and Cyperus spp. Occurrence along a toposequence. African Journal of Ecology, 51(3). 402-408. http://dx.doi.org/ 10.11111/aje.12050

Koné, B., Diatta, S., Oikeh, S., Gbalou, Y., Camara, M., Dohm, D. D., \& Assa, A. (2009). Estimation de la fertilité potentielle des ferralsols par la couleur: usage de la couleur en morphopédologie. Canadian Journal of Soil Science, 89(3), 331-342. http://dx.doi.org/10.4141/CJSS07119

Koné, B., Ettien, J. B., Amadji, G. L., Diatta, S., \& Camara, M. (2010b). Effets d'engrais phosphatés de différentes origines sur la production rizicole pluviale des sols acides en zone de forêt semi-montagneuse sous climats tropicaux: Cas des hyperdystricferralsols sous jachères en Côte d'Ivoire. Etude et Gestion des Sols, 17(1), 7-17. Retrieved from www.afes.fr/afes/egs/EGS_17_1_EGS_17_1_web_Kone.pdf

Koné B., Traoré, K., \& Touré, A., (2014). Basal Fertilizer Effects on Weed Occurrence and Rice Yield in Acid Upland Soil of West Africa at Bénin. Journal of Plant Sciences, 2(1). 14-22. http://dx.doi.org/10.11648/j.jps.20140201.14

Koné, B., Oikeh, S., Diatta, S., Somado, A., Kotchi, V., \& Sahrawat, K. S. (2011). Response of interspecifics and sativa upland rice to Mali phosphate rock and soluble phosphate fertilizer. Archieve of Agronomy and Soil 
Science, 57(4), 421-432. http://dx.doi.org/10.1080/03650340903563382

Koné, B., Saïdou, A., Camara, M., \& Diatta, S. (2010a). Effet de différentes sources de phosphate sur le rendement du riz sur sols acides: Optimisation du phosphate sur un hyperdystricferralsol. Agronomie Africaine, 22(1), 55-63. Retrieved from www.ajol.info > Journal Home

Lahlou, M. (2004). Methods to study phytochemistry and bioactivity of essential oils. Phytotherapy Research, 18, 435-448. http://dx.doi.org/10.1002/ptr.1465

Lawless, J. (1995). The Illustrated Encyclopedia of Essential oils. The complete guide to the use of oils in aromatherapy and herbalism. London: Harper Collins. Retrieved from www.amazon.fr/The-Illustrated-Encyclopedia-Essential-Oils/dp/1852307218

Loza-Tavera, H. (1999). Monoterpenes in essential oils. United States: Springer. http://dx.doi.org/10.1007/978-1-4615-4729-7_5

Maia, J. G. S., Silva, M. H. L., Andrade, E. H. A., \& Carreira, L. M. M. (2005). Essential Oil Variation in Lippia glandulosa Schauer. Journal of Essential Research, 17(6), 676-680. http://dx.doi.org/10.1080/10412905.2005.9699030

Marschner, H., \& Cakmak, I. (2006). Mechanism of phosphorus-induced zinc deficiency in cotton. II. Evidence for impared shoot control of phosphorus uptake and translocation under zinc deficiency. Physiologia Plantarum, 68(3). 491-496. http://dx.doi.org/10.1111/j.1399-3054.1986.tb03387.x

Mwangui, J. W., Addae-Mensah, I., Muriuki, R., Lwande, W., \& Hassanali, A. (1992). Essential oils of Lippia m ultiflora species in Kenya IV. Maize weevil (Sitophilus zeamais) repellancy and larvicidal activity. International Journal of Crude Drug Research, 30, 9-16. http://dx.doi.org/10.3109/13880209209054622

Nes, W. R., \& McKean, M. L. (1977). Biochemistry of steroids and other isoprenoids. Baltimore: University park press.

Noamesi, B. K., Adebayo, G. I., \& Bamgbose, S. O. (1985). The vascular actions of aqueous extract of Lippia multiflora. Planta Med, 51(3), 256-258. http://dx.doi.org/10.1055/s-2007-969472

Oladimeji, F. A., Orafidiya, O. O., Ogunniyi, T. A. B., \& Adewunmi, T. A. (2000). Pediculocidal and scabicidal properties of Lippia multiflora (Verbenaceae) essential oil. Journal of Ethnopharmacology, 72(2), 305-311. http://dx.doi.org/10.1016/S0378-8741(00)00229-4

Olle, M., \& Bender, I. (2010). The content of oils in umbelliferous crops and its formation. Agronomy Research, 8(3), 687-696. Retrieved from http://agronomy.emu.ee/vol08Spec3/p08s322.pdf_

Oussou, K. R., Yolou, S., Boti, J. B., Guessennd, K. N., Kanko, C., Ahibo, C., \& Casanova, J. (2008). Etude chimique et activité antidiarrheique des huiles essentielles de deux plantes aromatiques de la pharmacopée ivoirienne. European Journal of Scientific Research, 24(1), 94-103. Retrieved from http://hal.archives-ouvertes.fr/hal-00593500

Pansu, M., \& Gautheyrou, J. (2003). L'analyse du sol - minéralogique, organique et minérale (2ème ed.). Paris: Springer-verlag.

Pearlstine, E. (2006). Skin treatments using essential oils. Aromascents Journal, 36. Retrieved from http://www.tambela.com/articles/aromatherapy-skintreatment.php

Pham, H. C. \& Koffi, Y. (1988). Comparative effects on TXA2 biosynthesis of products extracted from Lippia multiflora Moldenke leaves. Prostaglandins, Leukotrienes and Essential Fatty Acids, 34(2), 83-88. http://dx.doi.org/10.1016/0952-3278(88)90067-1

Porspi, A. (2007). Ghana herbal pharmacoiea. Ghana: Science and technology policy research institute, council for scientific and industrial research.

Programme des Nations Unies pour le Développement. (2013). A propos de la Côte d'Ivoire: Données nationales. Banque mondiale: Pnud/rdh. Retrieved from http://www.ci.undp.org/content/cotedivoire/fr/home/ country.info

Purseglove, J. W., Brown, E. G., Green, C. L., \& Robbins, S. R. J. (2008). Spices. Cambridge Journals: Experimental Agriculture, 18(3), 330-330. http://dx.doi.org/10.1017/S0014479700013934

Rhuhe, R.V., \& Walker, P. H. (1968). Hillslope models and soil formation: II. Open systems. Proceedings of $9^{\text {th }}$ Congress of the International Soil Science Society. Adelaide, Autralia: International Soil Science Society. Retrieved from http://geomorphometry.org/content/hillslope-models-and-soil-formation-ii-open-systems 
Rumasz-Rudnicka, E. Koszanski, Z., \& Woroniecki, T. (2008). Efekty Nawadniania Niektorych Warzyw. Acta Agrophysica, $11(2), \quad 509-517 . \quad$ Retrieved from www.old.acta-agrophysica.org/artykuly/acta_agrophysica/ActaAgr_157_2008_11_2_509.pdf

Tunctürk, R., \& Tunctürk, M. (2006). Effects of different phosphorus levels on the yiled and quality components of Cumin (Cuminum cyminum L.). Research Journal of Agriculture and Biological Sciences, 2, 336-340. Retrieved from www.aensiweb.com/aeb/2011/371-374.pdf

Udoh, B. T., Ogunkunle, A. O., \& Ndaeyo, N. U. (2007). Influence of soil series and physico-chemical properties on weed flora distribution at moor plantation Ibadan, southwestern Nigeria. Journal of Agriculture \& Social Sciences, 3(2). 55-58. Retrieved from www.fspublishers.org/published_papers/33116_..pdf

Wambeke, V. A. (1974). Ferralsols Part 1. Management properties of ferralsols. Rome: Fao land and water division. Retrieved from http://www.fao.org/docrep/x5867e00.htm

Wambeke, V. A. (2003). Properties and managment of soils in the Tropics. European Journal of Soil Science, 56(2), 279-280. http://dx.doi.org/10.1111/j.1365-2389.2004.0694i.x

Wayne, S. (2001). The nitrogen and acidity story. Agronomic Acumen: Newsletter, 80. Retrieved from http://www.agronomy.com.au/newsletter.htm

Webster, R., \& Olivier, M. A. (1990). Statistical methods for soil and land resource survey. United States of America, USA: Oxford university press. Retrieved from www.amazon.com/statistical-methods-resource-spatial-information/dp/0198233167

Yao-Kouame, A., \& Fako, K. (2008). Biochemical characteristic of Lippia multiflora (Verbenaceae) leaves with respect to fertilizer applied to the soil. J. Plant Sci., 3(4), 287-291. http://dx.doi.org/10.3923/jps.2008.287.291

Yao-kouamé, A., Nangah, K. Y., Alui, K. A., N'guessan, K. A., Yao, G. F., \& Assa, A. (2009). Pedo-landscape and development of Lippia multiflora in Southern Côte d'Ivoire. Journal of Environmental Science and Technology, 2(1), 56-62. http://dx.doi.org/10.3923/jest.2009.56.62

\section{Copyrights}

Copyright for this article is retained by the author(s), with first publication rights granted to the journal.

This is an open-access article distributed under the terms and conditions of the Creative Commons Attribution license (http://creativecommons.org/licenses/by/3.0/). 